\title{
Hubungan antara Skor GCS dengan Kadar C-Reactive Protein (CRP) Pasien Cedera Otak Traumatik di IGD RSUD Ulin Banjarmasin
}

\author{
Gusti M F Suharto", Kenanga M Sikumbang ${ }^{* *}$, Dewi I N Pratiwi**) \\ ${ }^{*}$ Fakultas Kedokteran Universitas Lambung Mangkurat Banjarmasin, ${ }^{* *}$ Departemen Anestesiologi dan Terapi \\ Intensif, Fakultas Kedokteran, Universitas Lambung Mangkurat-RSUD Ulin, Banjarmasin, ${ }^{* * *}$ Departemen \\ Patologi Klinik, Fakultas Kedokteran, Universitas Lambung Mangkurat/RSUD Ulin, Banjarmasin.
}

\begin{abstract}
Abstrak
Latar Belakang dan Tujuan: Pada cedera otak traumatik (COT) terjadi perubahan tingkat kesadaran dan neurologis pasien, sehingga perlu dilakukan penilaian skor GCS untuk mengkategorikan tingkat keparahan COT. Saat terjadinya COT, akibat dari pengeluaran mediator inflamasi, hati akan mengeluarkan suatu penanda pertama inflamasi, yaitu c-reactive protein (CRP). Tujuan penelitian ini untuk mengetahui apakah terdapat hubungan antara skor GCS dengan kadar CRP pasien COT di IGD RSUD Ulin Banjarmasin.

Subjek dan Metode: Penelitian ini menggunakan studi desain observasional analitik dengan rancangan potong lintang. Data diambil secara prospektif dengan metode consecutive sampling pada pasien COT yang masuk ke IGD RSUD Ulin Banjarmasin periode Juli-September 2018 yang memenuhi kriteria inklusi dan eksklusi.

Hasil:Didapatkan 53 subjek terdiri dari 42 pasien laki-laki dan 11 pasien perempuan dengan distribusi $22(41,5 \%)$ pasien COT ringan, $20(37,7 \%)$ pasien COT sedang, dan 11 (20,8\%) pasien COT berat. Pengukuran kadar CRP didapatkan rata-rata $4,64 \mathrm{mg} / \mathrm{l}$ pada COT ringan, $18,00 \mathrm{mg} / 1$ pada COT sedang, dan $26,73 \mathrm{mg} / \mathrm{dl}$ pada COT berat. Analisis data menggunakan uji Kruskal-Wallis dengan tingkat kepercayaan $95 \%$ menunjukan peningkatan kadar CRP seiring dengan semakin beratnya COT $(\mathrm{p}=0,034)$, analisis Post Hoc menggunakan Mann-Whitney Test didapatkan perbedaan bermakna peningkatan kadar CRP antara pasien COT sedang berat dibandingkan COT ringan. Simpulan: Terdapat hubungan antara skor GCS dengan kadar CRP pada pasien cedera otak traumatik.
\end{abstract}

Kata kunci: cedera otak traumatik, c-reactive protein, glasgow coma scale (GCS)

JNI 2019; 8 (3): 153-59

\section{Correlations between GCS Score and C-Reactive Protein (CRP) in Patients with Traumatic Brain Injury at Emergency Departement of Ulin General Hospital Banjarmasin}

\begin{abstract}
Backgound and Objective: In traumatic brain injury (TBI), the level of severity could be assessed by GCS, so it is necessary to measure the GCS score to categorize the severity of TBI. TBI may followed by inflammatory mediators cell and one of inflammation marker released by liver, namely c-reactive protein (CRP). The purpose of this study is to analyze correlation between GCS scores and CRP levels in patients with traumatic brain injury at the emergency departement of Ulin General Hospital Banjarmasin.

Subject and Method: This study is a analytic observational study with cross sectional design. Data acquired prospectively with consecutive sampling method in TBI patients who entered the emergency department of Ulin General Hospital in the period from July-September 2018 that fulfilled inclusion criteria and exclusion criteria.

Result: We obtained 53 subjects consisted of 42 males and 11 females with a distribution of $22(41.5 \%)$ mild TBI patients, 20 (37.7\%) modarate TBI patients, and $11(20,8 \%)$ severe TBI patients. Measurements of CRP levels were obtained at an averange of $4.64 \mathrm{mg} / \mathrm{l}$ in mild TBI, $18.00 \mathrm{mg} / \mathrm{l}$ in moderate TBI, and $26.73 \mathrm{mg} / \mathrm{l}$ in severe TBI. There was correlation between the increasing of CRP levels with severity of TBI using Kruskal-Wallis test with a confidence level of $95 \%(\mathrm{p}=0.034)$, in Post Hoc analysis using Mann-Whitney test, there was significant differences in elevated CRP levels between moderate-severe TBI patients compared to mild TBI patients.

Conclusion: It was concluded that there was a corellation between GCS scores and CRP levels in TBI patients.
\end{abstract}

Key words: traumatic brain injury, c-reactive protein, glasgow coma scale (GCS)

JNI 2019; 8 (3): 153-59 


\section{Pendahuluan}

Cedera otak traumatik (COT) merupakan masalah kesehatan yang dihadapi dunia dengan angka kejadian yang masih tinggi. Central of Disease Control and Prevention (CDC) pada periode 1997-2007 mendapatkan insidensi COT sekitar 1,7 juta per tahun di Amerika Serikat dengan mortalitas 30,5\%. Data epidemiologi di Eropa menyebutkan insidensi COT sebanyak 235 per 100.000 kasus dengan case fatality rate (CFR) 11 per 100 kasus. ${ }^{1}$ Hasil Riskesdas tahun 2013 menunjukan insidensi cedera COT dengan CFR sebanyak 100.000 jiwa meninggal dunia. ${ }^{2}$ Instalasi Gawat Darurat RSUD Ulin Banjarmasin tahun 2014 melaporkan bahwa COT termasuk dalam 10 besar penyakit terbanyak bedah dengan angka 1.187 dari 4.406 kasus (27\%), dengan insidensi terbanyak adalah COT ringan $64,6 \%$ (767 kasus), kemudian COT sedang16,7\% (198 kasus), dan COT berat 18,7\% (222 kasus). ${ }^{3}$

Pada cedera otak traumatik (COT) terjadi kerusakan kompleks baik berupa luka tertutup maupun luka yang menembus kulit dan melibatkan struktur lapisan kepala, mulai dari kulit sebagai lapisan paling luar sampai dengan tulang tengkorak, vaskular otak, ataupun jaringan otak sebagai cedera kranio-serebral. ${ }^{4,5}$ Penilaian tingkat keparahan dengan cepat dan tepat dari COT dapat menggunakan Glasgow Coma Scale (GCS). Berdasarkan skor GCS, klasifikasi COT terbagi menjadi COT ringan (13-15), COT sedang (9-12), dan COT berat (3-8). ${ }^{6}$ Cedera otak traumatik akan merangsang sel-sel sistem saraf pusat untuk menghasilkan berbagai mediator inflamasi.

Setidaknya, ada tiga sitokin penting yang dihasilkan oleh mikroglia dan astrosit setelah cedera, yaitu interleukin-1 $\beta$ (IL-1 $1 \beta)$, tumor nekrosis faktor $\alpha(\mathrm{TNF} \alpha)$, dan interleukin-6 (IL-6). ${ }^{7}$ IL-6 yang dihasilkan akan merangsang hepatosit untuk meningkatkan produksi protein fase akut seperti $C$-reactive protein. Protein ini akan merefleksikan proses terjadinya inflamasi sehingga terjadi peningkatan dari kadar normal. ${ }^{8}$ Pada populasi umum nilai $C$-Reactive Protein (CRP) berkisar $10 \mathrm{mg} / 1$ dan meningkat dengan cepat sebagai respon terhadap trauma, inflamasi dan infeksi, juga akan menurun dengan cepat seiring dengan perbaikan kondisi. Waktu optimal untuk mengukur kadar CRP yang menunjukan kerusakan jaringan kemungkinan adalah 3 hari setelah COT. Namun, pembentukan CRP sudah mulai meningkat dalam waktu 4-8 jam dengan konsentrasi puncak dalam 36-50 jam dan terus meningkat secara signifikan sampai sekitar 5-7 hari. ${ }^{9}$ Di RSUD Ulin Banjarmasin penilaian beratnya COT dilakukan dengan menggunakan skor GCS yang bersifat objektif, namun masih perlu dilakukan pemeriksaan yang bersifat kuantitatif untuk mengetahui beratnya COT. Selain itu, penelitian menggunakan CRP sebagai penanda inflamasi cedera otak traumatik sebelumnya belum pernah dilakukan di RSUD Ulin Banjarmasin. Berdasarkan uraian diatas maka akan dilakukan penelitian untuk mengetahui ada tidaknya hubungan antara skor GCS dengan kadar CRP sebagai penanda inflamasi pasien COT di IGD RSUD Ulin Banjarmasin.

\section{Subjek dan Metode}

Penelitian ini merupakan observasional analitik dengan rancangan cross sectional. Sampel penelitian adalah 53 pasien yang telah memenuhi kriteria inklusi dan eksklusi dan telah menandatangani lembaran informed consent.

Kriteria inklusi sampel penelitian adalah sebagai berikut: a.) Pasien dengan usia 18-60 tahun; b.) Pasien yang datang ke IGD RSUD Ulin Banjarmasin dalam waktu lebih dari 4 jam dan kurang dari 24 jam dengan gambaran CT scan memperlihatkan adanya epidural hematoma (EDH), subdural hematoma (SDH), intracerebral hematoma (ICH), atau kombinasi. Kriteria eksklusi sampel penelitian adalah sebagai berikut: a.) Pasien multipel trauma dengan cedera pada minimal dua sistem organ dengan derajat keparahan yang cukup tinggi disertai dengan reaksi sistemik akibat trauma; b.) Pasien dengan gangguan fungsi hati dengan peningkatan AST $>200 \mathrm{iu} / 1$ dan ALT>300iu/1.

Peneliti akan melakukan observasi dengan cara menilai skor GCS setelah pasien stabil untuk 
menentukan tingkat keparahan COT yang dikategorikan menjadi COT ringan (13-15), COT sedang (9-12), dan COT berat (3-8) pada saat pasien datang ke IGD RSUD Ulin Banjarmasin, selanjutnya pasien akan dilakukan pengambilan darah untuk pemeriksaan kadar CRP dengan metode aglutinasi. Data yang terkumpul akan ditabulasi dan dianalisis hasilnya menggunakan uji Kruskal-Wallis.

\section{Hasil}

Telah dilakukan penelitian mengenai hubungan beratnya cedera kepala berdasarkan skor GCS dengan kadar CRP pada pasien COT di IGD RSUD Ulin Banjarmasin pada bulan JuliSeptember 2018. Pasien COT di IGD RSUD Ulin Banjarmasin berdasarkan (Tabel 1) didapatkan 53 pasien dengan distribusi kejadian tertinggi yaitu COT ringan, kemudian diikuti COT sedang dan

Tabel 1. Karakteristik Umum Subjek Penelitian Hubungan Skor GCS dengan Kadar CRP Pasien Cedera Otak Traumatik di IGD RSUD Ulin Banjarmasin.

\begin{tabular}{|c|c|c|c|}
\hline Variabel & $\mathrm{n}(\%)$ & $\operatorname{mean} \pm \mathrm{SD}$ & $\mathbf{p}$ \\
\hline \multicolumn{4}{|l|}{ Distribusi COT } \\
\hline Ringan & $22(41,5 \%)$ & & 0,000 \\
\hline Sedang & $20(37,3 \%)$ & & 0,000 \\
\hline Berat & $11(20,8 \%)$ & & 0,010 \\
\hline \multicolumn{4}{|l|}{ Usia (tahun) } \\
\hline $18-40$ & $19(35,8 \%)$ & & 0,000 \\
\hline $41-60$ & $34(64,2 \%)$ & & 0,050 \\
\hline \multicolumn{4}{|l|}{ Jenis kelamin } \\
\hline Laki-laki & $42(79,2 \%)$ & & 0,025 \\
\hline Perempuan & $11(20,8 \%)$ & & 0,200 \\
\hline \multicolumn{4}{|c|}{ Waktu pengambilan darah (jam) a } \\
\hline COT ringan & & $6,26 \pm 1,27$ & 0,200 \\
\hline COT sedang & & $7,05 \pm 2,39$ & 0,134 \\
\hline COT berat & & $7,64 \pm 3,66$ & 0,000 \\
\hline \multicolumn{4}{|l|}{ Mekanisme b } \\
\hline KLL & $45(83,9 \%)$ & & 0,002 \\
\hline Terjatuh & $8(15,1 \%)$ & & 0,200 \\
\hline \multicolumn{4}{|l|}{ Kadar CRP } \\
\hline COT ringan (mg/l) & & $4,64 \pm 6,12$ & \\
\hline Normal & $11(50 \%)$ & & \\
\hline Meningkat & $11(50 \%)$ & & \\
\hline COT sedang (mg/l) & & $18,00 \pm 19,07$ & \\
\hline Normal & $6(30 \%)$ & & \\
\hline Meningkat & $14(70 \%)$ & & \\
\hline COTberat (mg/l) & & $26,73 \pm 37,11$ & \\
\hline Normal & $4(37 \%)$ & & \\
\hline Meningkat & $7(63 \%)$ & & \\
\hline
\end{tabular}

*COT: Cedera Otak Traumatik; KLL: Kecelakaan Lalu Lintas; CRP: C-Reactive Protein. aWaktu dari terjadinya cedera sampai dilakukan pengambilan darah.

bMekanisme trauma yang menyebabkan terjadinya cedera otak traumatik. 
Tabel 2. Hubungan Skor GCS dengan Kadar CRP Pasien Cedera Otak Traumatik di IGD RSUD Ulin Banjarmasin.

\begin{tabular}{llll}
\hline GCS & $\mathrm{N}$ & CRP & $\mathrm{p}$ \\
\hline COT ringan & 22 & $4,64 \pm 6,12$ & \\
COT sedang & 20 & $18,00 \pm 19,07$ & 0,034 \\
COT berat & 11 & $26,73 \pm 37,11$ & \\
\hline
\end{tabular}

Ket: data disajikan dalam mean \pm standar deviasi. Uji statistik menggunakan uji Kruskal-Wallis. Bermakna jika nilai $\mathrm{p} \leq 0,05$.

COT berat. Berdasarkan pembagian usia menurut Hurlock, penelitain ini membagi usia menjadi dua kategori yaitu usia 18-40 tahun dan 41-60 tahun, hasil penelitian ini (Tabel 1) didapatkan bahwa pasien COT pada usia dewasa muda lebih banyak dibandingkan usia dewasa lanjut. Pada penelitian ini berdasarkan jenis kelamin (Tabel 1) didapatkan pasien COT yang terbanyak adalah laki-laki dibandingkan perempuan. Mekanisme penyebab COT dari penelitian ini adalah kecelakaan lalu lintas dengan jumlah yang paling banyak dan selanjutnya akibat terjatuh.

Berdasarkan (Tabel 1) pada pengukuran kadar CRP didapatkan bahwa rata-rata peningkatan CRP paling tinggi terdapat pada pasien COT berat diikuti dengan COT sedang dan COT ringan, sehingga secara tabulasi data menunjukan bahwa semakin rendah skor GCS maka semakin tinggi kadar CRP pasien COT. Setelah dilakukan uji normalitas data dengan uji Kolmogorov-Smirnov, data yang dihasilkan tidak terdistribusi normal, sehingga syarat uji ANOVA tidak terpenuhi dan dilakukan uji statistik dengan uji Kruskal-Wallis (Tabel 5.1) dan diperoleh nilai $\mathrm{p}=0,034$. Dengan demikian, hipotesis yang diajukan dapat diterima bahwa terdapat hubungan skor GCS dengan kadar CRP pasien COT di IGD RSUD Ulin Banjarmasin. Analisis Post Hoc menggunakan uji Mann Whitney U Test, pada pasien COT ringanCOT sedang berat didapatkan nilai $\mathrm{p}=0,009$, sehingga terbukti terdapat hubungan bermakna peningkatan kadar CRP pada COT sedang berat dari pada COT ringan. Secara statistik dalam penelitian ini ditemukan adanya hubungan bermakna $(\mathrm{p}=0,009)$ kadar CRP antara pasien COT ringan-COT sedang berat. Akan tetapi tidak terdapat hubungan bermakna kadar CRP antara pasien COT sedang-COT berat $(\mathrm{p}=0,983)$.

\section{Pembahasan}

Pada hasil penelitian ini didapatkan distribusi pasien COT tertinggi adalah COT ringan diikuti sedang dan berat. Hasil ini sebanding dengan penelitian yang dilakukan di Rumah Sakit Cipto Mangunkusumo Jakarta pada tahun 2005 yang menyatakan bahwa dari 172 pasien COT, sebanyak 122 pasien (71\%) mengalami COT ringan, 37 pasien (21\%) mengalami COT sedang, dan 13 pasien $(8 \%)$ mengalami COT berat. ${ }^{10}$ Pasien COT berat lebih sedikitnya dibandingkan dengan pasien COT ringan atau sedang dikarenakan kebanyakan pasien dengan COT berat mengalami kematian ditempat kejadian sebelum ditransportasikan menuju rumah sakit, selain itu juga pasien dengan COT berat yang masuk IGD rumah sakit sering kali memiliki kondisi yang sudah sangat buruk, pasien banyak yang meninggal sebelum atau saat dilakukan tindakan resusitasi dan belum sempat dilakukan pemeriksaan laboratorium. ${ }^{11}$

Penelitian ini menunjukan bahwa usia dewasa muda merupakan kelompok usia dengan pravelensi tertinggi COT. Hasil ini sama dengan penelitian yang dilakukan pada tahun 2003 di Makassar, tentang karakteristik pasien korban kecelakaan lalu lintas yang dimasuk ke IGD RSU Labuan Baji Makassar periode Januari-Desember 2002 mendapatkan hasil bahwa dari 327 kasus kecelakaan lalu lintas sebanyak 204 kasus terjadi pada golongan usia 15-49 tahun (62,3\%), 31 kasus pada golongan usia diatas 50 tahun $(9,4 \%)$, dan 81 kasus terjadi pada usia dibwah 15 tahun $(28,3 \%) .{ }^{12}$ Jenis kelamin dengan kejadian COT tertinggi pada penelitian ini adalah laki-laki. Hasil penelitian ini juga sama dengan penelitian yang dilakukan pada tahun 2013 di RSU Sanglah Bali yaitu dari 60 pasien COT, terdapat 43 pasien laki-laki $(71,7 \%)$ dan 17 pasien perempuan $(28,3 \%) .{ }^{13}$ Penelitian lain yang dilakukan pada tahun 2008 di Makassar menunjukan bahwa dari 288 kasus kecelakaan lalu lintas, lakilaki memiliki kasus terbanyak yaitu 252 kasus (88\%), sedangkan perempuan 36 kasus (13\%). ${ }^{12}$ Penelitian lainnya lagi mendapatkan hasil bahwa 
dari 621 pasien COT paling banyak terjadi pada laki-laki 435 pasien (70,05\%) dan perempuan 186 pasien $(29,95 \%) \cdot{ }^{13}$ Kondisi ini menyerupai hasil penelitian yang dilakukan pada tahun 2012 di Surabaya yang menyebutkan bahwa pengendara motor laki-laki memiliki resiko kecelakaan dua kali lipat lebih besar dibandingkan perempuan. ${ }^{14}$ Individu-individu pengguna jalan raya cenderung lebih banyak yang memanfaatkan kendaraan dalam hal ini pengendara adalah pada laki-laki dibandingkan perempuan sehingga kejadian kecelakaan lalu lintas yang menjadi faktor utama penyebab COT lebih cenderung pada laki-laki dibandingkan perempuan. ${ }^{12}$ Kecelakaan lalu lintas merupaka penyebab utama COT pada hasil penelitian ini. Hal ini didukung oleh penelitian lain yang dilakukan pada tahun 2012, yaitu penyebab utama COT adalah kecelakaan lalu lintas, kecelakaan kerja, jatuh dan tindakan kekerasan. ${ }^{12}$ Hasil penelitian di India pada 244 pasien COT juga mendukung, yaitu didapatkan hasil kecelakaan lalu lintas merupakan penyebab utama COT (67\%), yang diikuti dengan terjatuh dari ketinggian (28\%), dan sisanya (5\%) termasuk tindakan kekerasan atau kejatuhan suatu objek. ${ }^{15}$ Dari hasil penelitian ini didapatkan bahwa terdapat hubungan skor GCS dengan kadar CRP pasien COT di IGD RSUD Ulin Banjarmasin. Penemuan ini didukung oleh hasil penelitian tahun 2010 di RS Sanliurfa Turki yang menggunakan GCS dan CRP sebagai penanda inflamasi COT pada 100 pasien, didapatkan secara statistik bahwa ada perbedaan bermakna antara tingginya kadar CRP pada serum dengan pasien yang memiliki GCS kurang dari $12(\mathrm{p}=0,001) \cdot{ }^{16}$

Penelitian yang dilakukan di Rumah Sakit Chonan Korea menemukan bahwa kadar CRP yang tinggi ditemukan pada pasien dengan GCS yang rendah $(p=0,001)$, pasien dengan hasil outcome yang buruk $(\mathrm{p}=0,006)$, dan pasien yang menjalani operasi $(p=0,028) .{ }^{9}$ Penelitian lainnya lagi yang dilakukan di RSU Sanglah Bali dengan mengobservasi 60 pasien didapatkan bahwa CRP dalam darah yang ditemukan secara signifikan lebih tinggi pada kelompok dengan GCS 3-8 pada hari pertama $(p=0,001)$. Hal ini juga sesuai dengan penelitian lainnya yang mengamati 45 pasien COT, yaitu menunjukan bahwa peningkatan rata-rata CRP pada serum pasien COT berat secara signifikan lebih tinggi dari pada serum pasien COT ringan. Peningkatan ini paling signifikan pada hari pertama dan kedua terkait dengan tingkat keparahan trauma. ${ }^{17}$ Cedera otak traumatik menyebabkan terjadinya neuroinflamasi dari aktivasi respon imun bawaan, seperti melalui aktivasi jalur komplemen yang memicu respon mediator inflamasi dalam kompartemen intrakranial. Beberapa mediator endogen yang penting dalam neuroinflamasi adalah sitokin pro-inflamasi, kemokin, dan komplemen anafilatoksin yang mana akan memicu kemotaksis untuk diapedesis leukosit melewati blood-brain barrier (BBB) menuju ruang subaraknoid. Mediasi komplemen akibat cedera neuronal lambat setelah trauma kepala menyebabkan induksi dari disfungsi BBB oleh aktivasi jalur kompartemen klasik melalui $\mathrm{C} 1 \mathrm{q}$ dan anafilatoksin $\mathrm{C} 3 \mathrm{a}$ dan $\mathrm{C} 5 \mathrm{a}$, induksi dari apoptosis neuronal melalui reseptor $\mathrm{C} 5 \mathrm{a}$ (C5aR/CD88), dan mediasi lisisnya sel melalui membrane attack complex (MAC/C5b-9), diikuti inaktivasi dari mekanisme fisiologi perlindungan sel melawan komplemen penghancur. ${ }^{18}$

Proses inflamasi dan reaksi inflamasi yang terjadi akan mengawali suatu respon akut (acute phase response). Sel yang menjadi prekursor proses inflamasi pada umumnya adalah sel makrofag dan sel monosit. Sel tersebut melepas sitokin seperti IL dan TNF yang akan mengontrol migrasi leukosit masuk ke dalam jaringan dan menimbulkan proses inflamasi. Sitokin proinflamasi seperti IL-6 akan merangsang hepatosit untuk meningkatkan produksi protein fase akut. Protein fase akut akan aktif oleh karena hasil dari respon sistemik terhadap COT, kerusakan yang terjadi setelah COT akan mengakibatkan hepar mengeluarkan protein fase akut kedalam aliran pembuluh darah dimana salah satu protein fase akut tesebut adalah CRP. ${ }^{8}$ C-reaktif protein ini akan merefleksikan proses inflamasi sehingga terjadi peningkatan dari kadar normal. Pembentukan CRP akan meningkat dalam waktu 4 jam, jumlahnya bahkan meningkat dua kali dalam 8 jam setelah peradangan. Konsentrasi puncak akan tercapai dalam 36 jam sampai 50 jam setelah inflamasi. Kadar CRP akan terus meningkat seiring dengan 
proses inflamasi yang terjadi akibat kerusakan jaringan. Apabila terjadi penyembuhan akan terjadi penurunan kadar CRP secara cepat. Kinetik metabolisme CRP sejalan dengan derajat peradangan dan derajat penyembuhan yang terjadi. ${ }^{19}$

Penelitian ini mencatat bahwa pada pasien COT berat meskipun terdapat pasien yang mengalami peningkatan kadar CRP tertinggi, tetapi ada juga pasien yang tidak mengalami peningkatan dari kadar CRP. Hal ini terjadi karena dalam penelitian ini hanya menentukan beratnya COT berdasarkan GCS dan tidak memperhatikan diagnosis kelainan cedera otak traumatik yang terjadi. Faktor yang mempengaruhi terjadinya peningkatan kadar CRP pada pasien cedera otak traumatik adalah besarnya kerusakan dan inflamasi yang terjadi pada jaringan parenkim otak dan sekitarnya. Sedangkan pada pasien COT berat efek kerusakan terhadap jaringan otak dan sekitarnya berbeda-beda tergantung diagnosis kelainan cedera otak traumatik yang terjadi. Teori ini didukung dengan adanya hasil dari CRP yang relatif rendah dan normal oleh sebab perbedaan tingkat keparahan trauma, kerusakan dan inflamasi yang terjadi, lokasi kerusakan yang terjadi didalam otak, dan besarnya perdarahan yang terjadi. ${ }^{17}$ Selain itu perbedaan waktu dalam pengambilan darah juga akan mempengaruhi hasil dari CRP, pada penelitian ini rata-rata pengambilan darah dilakukan 7 jam setelah terjadinya cedera, sedangkan pada penelitian lain pengambilan darah dilakukan 12 jam setelah terjadinya cedera, bahkan di RS Chonan Korea melakukan pengambilan darah untuk pemeriksaan CRP setelah 48 jam terjadinya cedera. ${ }^{9} 16$ Hal ini disebabkan oleh karena peningkatan bermakna dari CRP terjadi 48 jam setelah COT. $^{20}$ Banyak penelitian lain juga telah menunjukan bahwa waktu puncak dari CRP adalah 48 jam setelah terjadinya cedera. Oleh sebab itulah, waktu 48 jam dipilih sebagai waktu pengukuran dari kadar CRP karena mampu menjelaskan peningkatan kadar CRP setelah terjadinya cedera pada semua pasien saat ini. ${ }^{20}$ Keterbatasan pada penelitian ini adalah teknik yang digunakan untuk mengukur kadar dari CRP yang dilakukan secara semikuantitatif, sehingga hasil penelitian ini meskipun menunjukan terdapat hubungan bermakna antara skor GCS dengan kadar CRP pasien COT, namun perbedaan bermakna peningkatan kadar CRP hanya ditemukan pada pasien COT ringan dengan COT sedang berat. Hal tersebut dikarenakan pada COT ringan meskipun terdapat peningkatan kadar CRP akibat terjadinya inflamasi, namun peningkatan tersebut hanya dapat diketahui jika terjadi aglutinasi. Individu-individu pengguna jalan raya cenderung lebih banyak yang memanfaatkan kendaraan dalam hal ini pengendara adalah pada laki-laki dibandingkan perempuan sehingga kejadian kecelakaan lalu lintas yang menjadi faktor utama penyebab COT lebih cenderung pada laki-laki dibandingkan perempuan. ${ }^{13}$

\section{Simpulan}

Kesimpulan dari penelitian ini adalah terdapat hubungan bermakna antara skor GCS dengan kadar CRP pasien cedera otak traumatik di IGD RSUD Ulin Banjarmasin. Saran untuk penelitian ini adalah perlu dilakukan penelitian lanjutan untuk mengetahui hubungan kadar CRP dengan luaran pasien COT.

\section{Daftar Pustaka}

1. Coronado VG, Likang $\mathrm{Xu}$, Basavaraju SV. Surveillance for traumatic brain injuryrelated death - United States, 1997 - 2007. Centers for Disease Control and Prevention. Morbidity and Mortality Weekly Report $2011 ; 60$.

2. Profil Kesehatan Indonesia 2007. Jakarta: Departemen Kesehatan RI. 2008; 26-28.

3. Laporan Tahunan Instalasi Gawat Darurat RSUD Ulin. Banjarmasin: RSUD Ulin; 2014.

4. Satyanegara, Hasan RY, Abubakar S. Ilmu Bedah Saraf Satyanegara. Edisi IV. Jakarta: PT Gramedia Pustaka Utama; 2014.

5. Wahjoepramono EJ. Cedera kepala. Lippo Karawaci: Fakultas Kedokteran Universitas Pelita Harapan; 2005. 
6. Sundstrom T, Grande PO, Juil N, Kock JC, Romner B, Wester K. Management of severe traumatic brain injury. Berlin Heidelberg: Springer-Verlag; 2012.

7. McKeating EG, Andrews PJD. Cytokines and adhesion molecules in acute brain injury. $\mathrm{Br} \mathrm{J}$ Anaest. 1998;80:77-84.

8. Ibrahim WN, Ahmed BU. Procalcitonin versus C-reactive protein: Usefulness as biomarker of sepsis in ICU patient. Int JCrit Ill Inj Sci. 2014;4(3):195-200.

9. Lee DG, Lee KS, Shim JJ, Yoon SM, and Bae HG. Prognostic value of the C-reactive protein levels in the head injury. J Kor Neurotraumatol Soc. 2005;1(1):57-60.

10. Wreksoatmodjo BR. Profil penderita cedera kepala di Unit Gawat Darurat sebuah rumah sakit di Jakarta. Majalah Kedokteran Damianus 2006; 5(2):137-43.

11. Naghibi T, Mina M, Faramarz D. Inflamation and outcome in traumatic brain injury: Does gender effect on survival and prognosis. J Clin Diagn Res. 2017:11(2);6-9.

12. Ramadhan Y. Hubungan skor GCS dengan masa PT dan aPTT pada pasien cedera kepala di IGD RSUD Ulin Banjarmasin. Karya Tulis Ilmiah. Universitas Lambung Mangkurat Banjarmasin; 2015.

13. Aprila H. Gambaran status fisiologi pasien cedera kepala di IGD RSUD Ulin Banjarmasin tahun 2016. Dinamika Kesehatan. 2017:8(1);237-49.
14. Grigorakos L, Alexopoulou A, Tzortzopoulou K, Stratouli S, Chorni D. A predictors of outcomein patients with severe traumatic brain injury. J Neurosci Clin Res. 2016:1(1);1-4.

15. Riskianasah A. Analisis pola tingkah laku pengendara sepeda motor di Kota Surabaya dengan driver behavior questionnaire. Karya Tulis Ilmiah. Institut Teknologi Sepuluh November Surabaya; 2012.

16. Dhandapani SS, Manju D, Sharma BS, Mahapatra AK. Prognostic significance of age in traumatic brain injury. J Neurosci Rur Prac. 2012:3(2);131-135.

17. Sogut O, Gulogu C, Orak M, Sayhan MB, Gokdemir MT, Ustundag M, Akkus Z. Trauma score and neuron-specific enolase, cytokine and C-reactive protein levels as predictor of mortality in patients with blunt head trauma. J Int Med Res. 2010;38:1708-20.

18. Bomba GIB, Maliawan S, Mahadewa TGB. High serum C-reactive protein as predictor of systemic inflamatory respones syndrome in severe head injury patients. BMJ. 2013; 2(1):38-41.

19. Schmidt OI, Christoph EH, Wolfgang E, Philip FS. Close head injury an inflammatory disease. J Brain Res Rev. 2005;48:388-99.

20. Litao MK, Deepak K. Erythrocyte sedimentation rate and c-reactive protein: How best to use them in clinical practice. Ped Ann. 2014;43(10):417-20. 